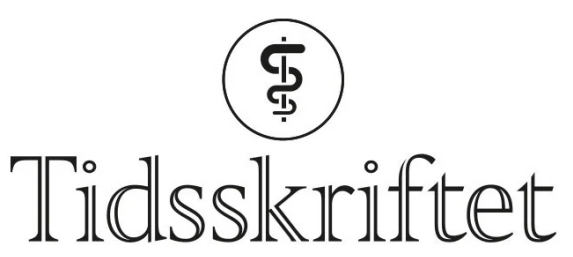

DEN NORSKE LEGEFORENING

\title{
Bildediagnostikk av pasienter med covid-19
}

KRONIKK

\section{TROND MOGENS AALØKKEN}

trond.mogens.aalokken@ous-hf.no

Trond Mogens Aaløkken er ph.d., spesialist i radiologi, overlege ved Avdeling for radiologi og nukleærmedisin, Oslo universitetssykehus og førsteamanuensis ved Universitetet i Oslo. Forfatteren har fylt ut ICMJE-skjemaet og oppgir ingen interessekonflikter.

\section{ANAGHA P. PARKAR}

Anagha P. Parkar er spesialist i radiologi og overlege ved Haraldsplass Diakonale Sykehus. Forfatteren har fylt ut ICMJE-skjemaet og oppgir ingen interessekonflikter.

\section{TOM-VEGARD MARKUSSEN}

Tom-Vegard Markussen er spesialist i radiologi og avdelingsoverlege ved Røntgenavdelingen, Universitetssykehuset Nord-Norge.

Forfatteren har fylt ut ICMJE-skjemaet og oppgir ingen interessekonflikter.

\section{HASEEM ASHRAF}

Haseem Ashraf er ph.d., spesialist i radiologi, overlege ved Bildediagnostisk avdeling, Akershus universitetssykehus og førsteamanuensis ved Klinikk for indremedisin og laboratoriefag, Universitetet i Oslo. Han er leder for Norsk forening for thoraxradiologi og styremedlem i Norsk lungekreftgruppe.

Forfatteren har fylt ut ICMJE-skjemaet og oppgir ingen interessekonflikter.

\section{GEORG KARL MYNAREK}

Georg Karl Mynarek er spesialist i radiologi og indremedisin og er overlege ved Avdeling for radiologi og nukleærmedisin, Oslo universitetssykehus.

Forfatteren har fylt ut ICMJE-skjemaet og oppgir ingen interessekonflikter.

\section{HARALD NES}

Harald Nes er spesialist i radiologi og overlege ved Radiologisk avdeling, Haugesund sjukehus. Han er styremedlem i Norsk radiologisk forening.

Forfatteren har fylt ut ICMJE-skjemaet og oppgir ingen interessekonflikter.

\section{FREDRIK MÜLLER}

Fredrik Müller er dr.med., spesialist i medisinsk mikrobiologi, professor og avdelingsleder ved Avdeling for mikrobiologi, Oslo universitetssykehus.

Forfatteren har fylt ut ICMJE-skjemaet og oppgir ingen interessekonflikter. 
Michael Schubert er spesialist i radiologi og overlege ved Radiologisk avdeling, Stavanger universitetssjukehus.

Forfatteren har fylt ut ICMJE-skjemaet og oppgir ingen interessekonflikter.

\section{ARVE 」ØRGENSEN}

Arve Jørgensen er ph.d., spesialist i radiologi, overlege ved Klinikk for bildediagnostikk, St. Olavs hospital og førsteamanuensis ved NTNU.

Forfatteren har fylt ut ICMJE-skjemaet og oppgir ingen interessekonflikter.

\section{SIRI MARIE BLOMBERG}

Siri Marie Blomberg er spesialist i radiologi og overlege ved Radiologisk avdeling, Haukeland universitetssjukehus.

Forfatteren har fylt ut ICMJE-skjemaet og oppgir ingen interessekonflikter.

\section{REIDAR BJØRNERHEIM}

Reidar Bjørnerheim er dr.med., spesialist i hjertesykdommer og seksjonleder/overlege ved Hjertemedisinsk avdeling, Oslo universitetssykehus.

Forfatteren har fylt ut ICMJE-skjemaet og oppgir ingen interessekonflikter.

\section{NILS EINAR KLøW}

Nils Einar Kløw er dr.med., spesialist i radiologi, seksjonsoverlege ved Avdeling for radiologi og nukleærmedisin, Oslo universitetssykehus og professor ved Institutt for klinisk medisin, Universitetet i Oslo.

Forfatteren har fylt ut ICMJE-skjemaet og oppgir ingen interessekonflikter.

\section{EINAR HOPP}

Einar Hopp er ph.d., spesialist i radiologi og avdelingsleder/overlege ved Avdeling for radiologi og nukleærmedisin, Oslo universitetssykehus.

Forfatteren har fylt ut ICMJE-skjemaet og oppgir ingen interessekonflikter.

\section{Covid-19 gir et mangefasettert sykdomsbilde, og ved utredning og oppfølging av pasienter er flere bildediagnostiske metoder aktuelle. Vi gjennomgår her indikasjoner og nytteverdi og presenterer bildeeksempler med typiske funn i ulike stadier av sykdommen. Ettersom viruspneumoni og akutt lungesviktsyndrom er fremtredende, er det spesielt lagt vekt på røntgen og CT av lungene.}

I den pågående pandemien må nytteverdien av bildediagnostikk balanseres mot tilgjengelige ressurser. Både krisens kapasitetsutfordringer og smittevernhensyn krever en strengt målrettet bruk. Behov for bildediagnostikk av pasienter med covid-19 skal håndteres på samme måte som andre pasientgrupper med utgangspunkt i klinisk vurdering, men alltid med behandlingsmessig forventet konsekvens. Se ramme 1 for våre anbefalinger.

\section{Ramme 1 Våre bildediagnostiske anbefalinger}

1. Behov for bildediagnostikk hos pasienter med covid-19 er en klinisk vurdering på samme måte som for andre pasientgrupper. Smittestatus skal ikke stå i veien for 
nødvendig diagnostikk og utredning.

2. For bildediagnostikk kreves en tydelig formulert behandlingsmessig konsekvens. 3. Røntgen thorax er verken sensitiv eller spesifikk for covid-19, og funn kan være normale i tidlige stadier av sykdommen

- Ved utredningstidspunktet er røntgen thorax indisert med tanke på differensialdiagnoser, men vil verken kunne utelukke eller bekrefte covid-19. Undersøkelsen er også viktig som basis for sykdomsprogresjon og senere kontroller.

- I forløpet av sykdommen er røntgen thorax indisert ved kontroll av medisinskteknisk utstyr, ved mistanke om komplikasjoner og i oppfølging og monitorering med potensiell behandlingsmessig konsekvens.

- Daglig rutinemessig røntgen thorax er ikke indisert hos stabile, intuberte pasienter.

4. CT thorax kan være sensitiv for covid-19-pneumoni, men er ikke spesifikk. Andre akutte interstitielle pneumonier kan gi lignende funn.

- CT bør ikke benyttes som screeningverktøy hos pasienter med milde eller ingen symptomer.

- Ved utredningstidspunktet kan CT benyttes ved uavklart tilstand, negativ polymerasekjedereaksjon (PCR) og klinisk mistanke om covid-19 samt når avklaring av smitte har betydelig konsekvens.

- I forløpet av sykdommen er CT indisert ved klinisk mistanke om komplikasjoner.

- Tilfeldig funn på CT-undersøkelse som gir mistanke om covid-19, bør føre til snarlig covid-19-utredning.

5. Sykdommen kan presentere seg med symptomer i andre organsystemer og kan fremkomme som bifunn ved radiologisk undersøkelse på annen indikasjon. Dette stiller krav til årvåkenhet og god organisering.

Internasjonalt er det raskt laget bakgrunnsdokumenter og anbefalinger om avbildning av pasienter med covid-19 (1-4). Dette er så langt (april 2020) ikke gjort på nasjonalt nivå i Norge. Vår erfaring er at både CT og røntgen thorax som primær diagnostisk metode er tatt i bruk i liten grad. Begge metoder er veletablerte og oftest selvsagte ved utredning og oppfølging av lungesykdom.

Klinikere bør gjøre seg kjent med CT- og røntgenfunn som er typiske for covid-19pneumoni. Derfor presenterer vi her slike funn i ulike stadier av sykdommen.

Bildediagnostiske funn ved covid-19 må betraktes som uspesifikke og overlappende med funn ved andre virale pneumonier og enkelte bakterielle pneumonier. Røntgenfunn alene utelukker ikke behovet for spesifikk virustesting og bør ikke sees på som erstatning for slik.

\section{Smittevernhensyn ved radiologiske metoder}

Verdens helseorganisasjon og Folkehelseinstituttet i Norge har definert smitteveien ved sars-CoV-2 som dråpesmitte, mens noen prosedyrer gir risiko for aerosolfrigjøring slik at situasjonen defineres som luftsmitte (5). Radiografer blir eksponert for smitte gjennom tett pasientkontakt med et stort antall pasienter. Radiologer vil kunne være utsatt ved ultralyd og intervensjonell virksomhet.

Desinfeksjon av radiologisk utstyr kan være komplisert og tidkrevende. I henhold til rutiner for kontaktsmitte desinfiserer man flater/punkter som pasienten og personalet har vært i direkte kontakt med under undersøkelsen med desinfeksjonssprit i tre minutter hvis det ikke er synlig søl. Synlig søl desinfiseres med godkjent desinfeksjonsmiddel i anbefalt tid. Hvis pasienten ikke har hatt på munnbind under undersøkelsen, bruker man 
dråpesmitteregimet, det vil si desinfiserer utstyr/flater innen to meters radius fra pasientens ansikt og som har blitt eksponert for dråper over noe tid (flere minutter). Utstyr, inventar og flater som pasienten bare kortvarig har passert, trenger ikke å desinfiseres, unntatt ved direkte kontakt. Ved aerosolgenerende prosedyrer desinfiserer man som ved luftsmitte.

Dersom man har flere maskiner av samme type, er det praktisk å allokere én til pasienter med dråpesmitte for å skjerme resten av virksomheten. Gode rutiner for transport av smittefarlige pasienter gjennom avdelingen basert på ventilasjon, mulighet for skjermet inngang og med ulike maskiner adskilt fra øvrig virksomhet er viktig. Covid-19 kan gi behov for monitorering med røntgen thorax på overvåkningspost og intensivavdeling. Vi vil anbefale å avsette et portabelt røntgenapparat til en definert smittekohort.

Covid-19 kan også ramme personer med annen sykdom. Vi må derfor være forberedt på å håndtere enhver diagnostikk, kartlegging og intervensjon også ved smitte av sars-CoV-2. Prosedyrer for dråpesmitte er derfor nå ekstra aktualisert ved angiografi, MR og nukleærmedisinske metoder.

I noen tilfeller vil symptomfri covid-19 bli mistenkt på grunn av funn ved CT av lungene gjennomført på annen indikasjon, for eksempel ved kontroll av kreft på radiologisk avdeling eller med PET/CT. For å unngå uklarhet omkring håndtering av smittevernregimet overfor disse pasientkategoriene anbefaler vi sterkt at alle sykehus planlegger for slike situasjoner.

\section{Mikrobiologisk diagnostikk}

Sars-CoV-2-RNA påvises ved sanntids (real time) PCR. Testene som tilbys i Norge, anses å ha svært høy analytisk sensitivitet og spesifisitet (므). Det anbefales penselprøve fra svelg og nasofarynks. Ved alvorlig lungeaffeksjon anbefales også prøve fra nedre luftveier $(7, \underline{8})$. Virusmengden i øvre luftveier er høyest ved symptomdebut (gjennomsnitt ca. $10^{6}$ viruskopier/ml) og faller etter 5-7 dager, men holder seg høy i nedre luftveier ved alvorlig sykdom $(9, \underline{10})$. Analysetiden er per i dag omtrent fire timer, svartid vil variere med logistikk og andre lokale forhold. PCR-hurtigtester med resultat på under én time er forventet å komme. Serologiske analyser påviser antistoffer mot sars-CoV-2 og etableres nå i norske laboratorier. Hurtigtester som påviser antigen eller antistoff mot sars-CoV-2 er tilgjengelige, men per april 2020 ikke kvalitetssikret (11).

\section{Røntgen thorax}

\section{KAPASITET}

Noen sykehus har røntgenlaboratorium i tilknytning til akuttmottaket, men for de fleste vil mobilt røntgenapparat være mest aktuelt. Fordelen med å gjøre undersøkelsen der pasienten er, er at smittespredning inn i røntgenavdelingen unngås.

\section{TEKNIKK OG BILDEKVALITET}

Kvaliteten på et røntgenbilde av thorax - og dermed forventet nytte - er best hvis undersøkelsen gjøres i to plan stående på et laboratorium, og dårligst hvis den gjøres med mobilt apparat på pasient liggende flatt i seng. Et høyere diafragmanivå og submaksimal inspirasjonsgrad vil kunne illudere mattglassfortetninger, og man må regne med redusert følsomhet for påvisning av alle aktuelle funn, inkludert pleuravæske og konsoliderte fortetninger. Bilde tatt i seng på stue er likevel eneste alternativ hos alvorlig syke pasienter.

FØLSOMHET OG FUNN

Røntgen thorax har lav sensitivitet for påvisning av mattglassfortetninger og kan vise «normale» funn tidlig i covid-19-sykdomsforløpet og hos asymptomatiske personer $(\underline{12}, 13)$. 
I et materiale fra Hongkong hadde $69 \%$ funn på røntgen thorax før behandling (baseline), men $9 \%$ hadde funn på røntgen thorax før positiv PCR (14). Sensitiviteten for røntgen thorax var $69 \%$ og for PCR $91 \%$. Vanligste røntgenfunn var bilateral konsolidering og mattglassfortetninger med perifer og kaudal distribusjon. Forandringene var mest uttalt 10-12 dager etter symptomdebut. Figur 1 og figur 2 viser typiske funn på røntgen thorax ved covid-19.

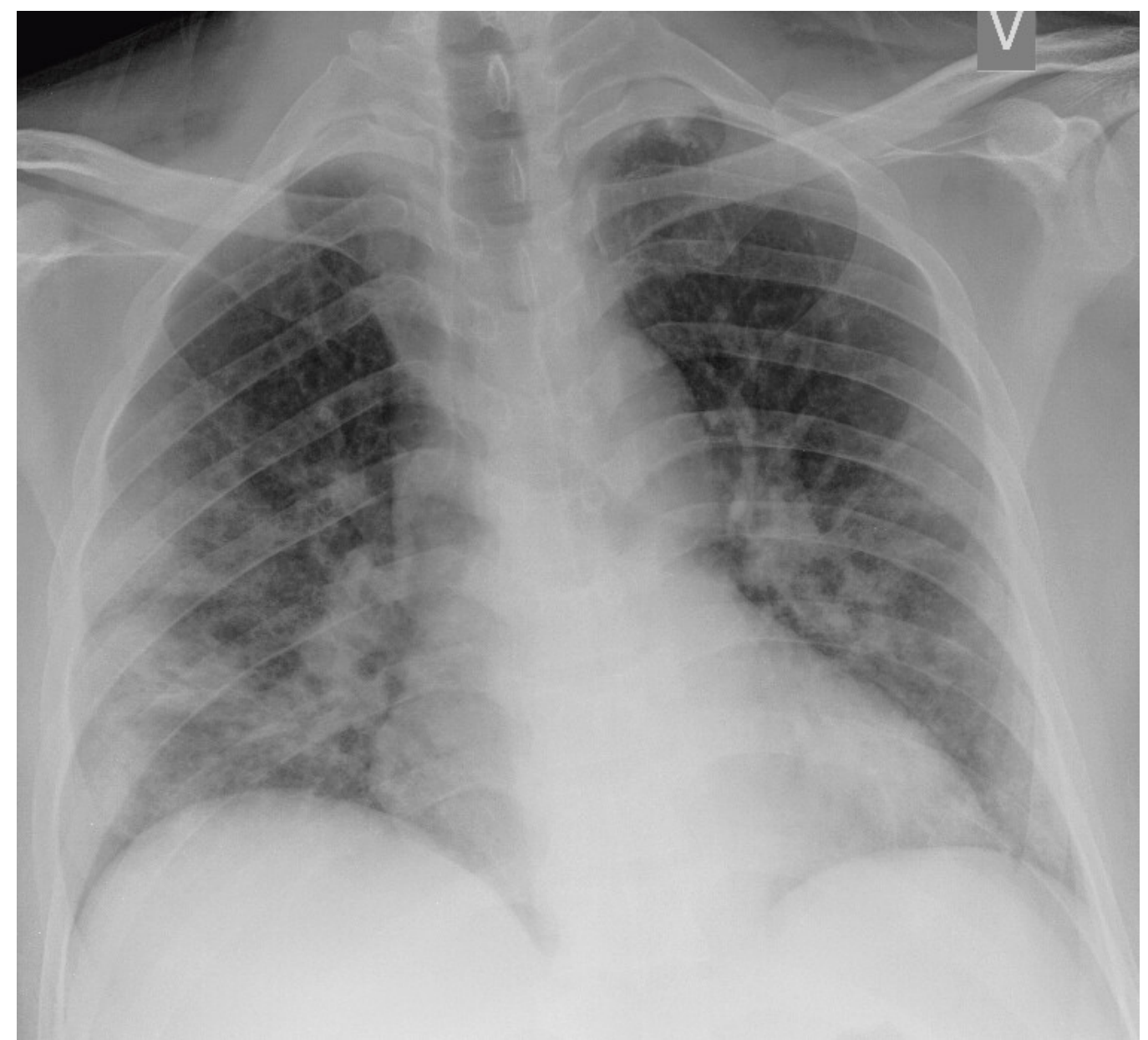

Figur 1 Pasient med covid-19 innlagt med redusert allmenntilstand, tørrhoste og økende dyspné. Røntgen thorax tatt liggende i seng fem dager etter symptomdebut viser løst mettede fortetninger, tydeligst i høyre midtfelt. 


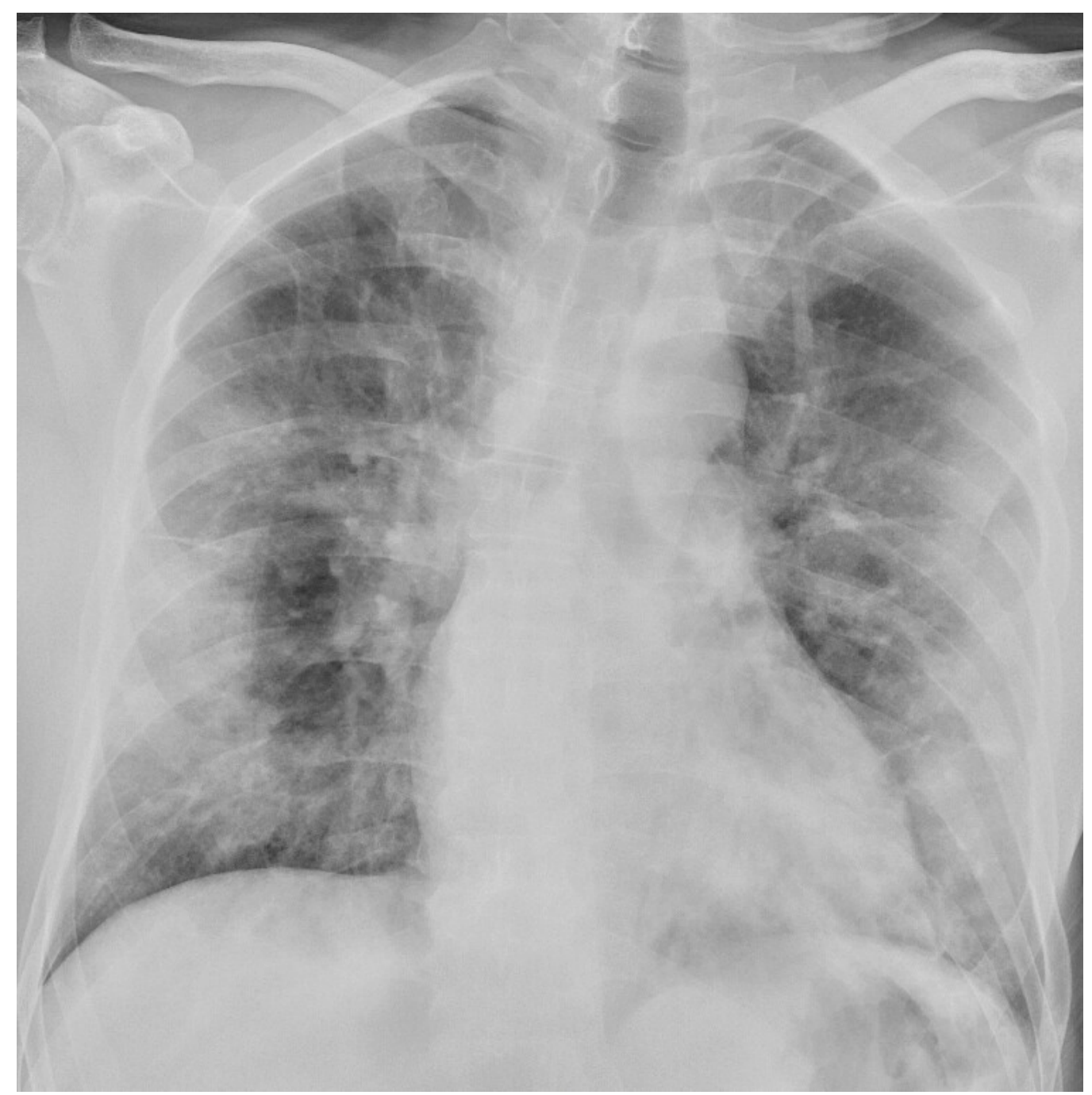

Figur 2 Pasient med covid-19 innlagt etter ti dager med hodepine og tørrhoste, siste tre dager økende dyspné. Røntgen thorax tatt sittende i seng ved innkomst viser bilaterale perifert distribuerte fortetninger, tydeligst i midtfeltene. Covid-19 ble bekreftet en dag senere.

INDIKASJONER

Pasienter med moderate symptomer skal utredes med bildediagnostikk i tråd med rutiner for luftveissykdom. Røntgen thorax anbefales imidlertid ikke som primær modalitet for spesifikk diagnostikk av covid-19, fordi et normalt røntgenbilde ikke utelukker sykdommen og fordi typiske funn heller ikke er spesifikke nok til å bekrefte den. Røntgen thorax kan likevel være indisert med tanke på differensialdiagnostikk.

Hos inneliggende pasienter kan et sengebilde i tidlig stadium være nyttig som sammenligningsgrunnlag for tolking av bilder tatt senere. Hos pasienter med alvorlig sykdom vil det være indisert med sengebilder for kontroll av medisinskteknisk utstyr (figur 3), men det er ikke indisert med daglig, rutinemessig røntgen thorax hos stabile pasienter. I forløpet av sykdommen vil det være indisert med sengebilde ved mistanke om komplikasjoner og ved oppfølging og monitorering av sykdomsprogresjon. 


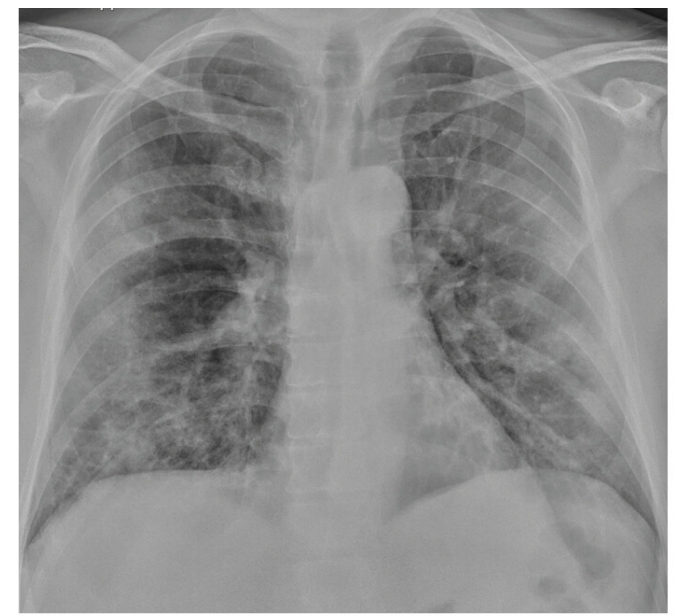

a

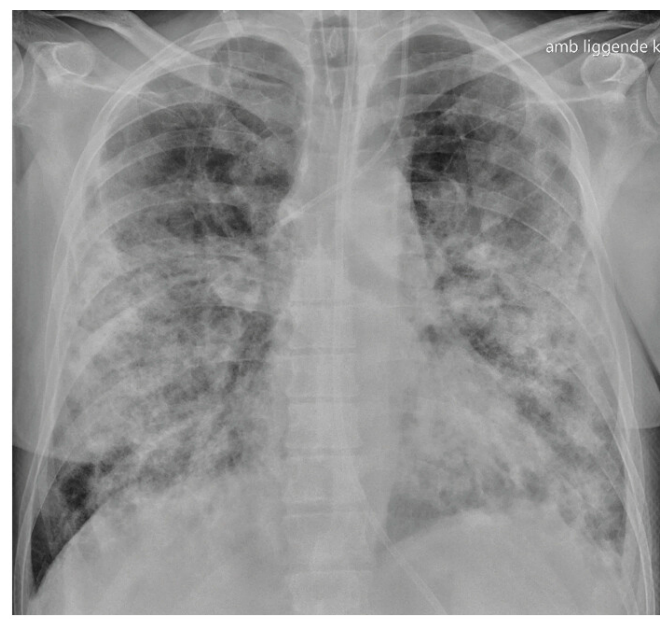

b

Figur 3 a) Pasient med covid-19. Røntgen thorax tatt sittende i seng med mobilt apparat 10 dager etter symptomdebut viser bilaterale overveiende løst mettede fortetninger bilateralt, tydeligst perifert. På grunn av økende hypoksi og slitenhet ble pasienten intubert to dager senere. b) Røntgen thorax tatt liggende i seng 20 dager etter symptomdebut viser betydelig progresjon med økende innslag av konsoliderte fortetninger. Det er fremdeles lite eller ingen pleuravæske. Bildet viser også ventrikkelsonde, sentralt venekateter og endotrakealtube.

\section{CT thorax}

\section{KAPASITET OG TILGJENGELIGHET}

Laboratoriekapasiteten for CT-undersøkelse vil være redusert fordi rengjøring etter unders $ø$ kelse av smittet pasient er tidkrevende. Potensiell nytte av undersøkelsen må veies mot belastningen som forflytningen påfører en kritisk syk pasient. Gode rutiner for forflytning av pasienten gjennom sykehuset forhindrer smitte. Pasienten bør utstyres med kirurgisk munnbind før transport.

TEKNIKK

Hvis indikasjonen er utbredelse av lungesykdom, er det ikke nødvendig å benytte kontrastmiddel intravenøst. Kontrastmiddel kan forviske fremstillingen av enkelte lungeforandringer, slik som mattglassfortetninger. CT-undersøkelsen må ha god nok kvalitet og tilstrekkelig stråledose til å fremstille subtil patologi. Rekonstruksjoner med tynne og tykkere snitt med kantforsterkende og bløt algoritme er nødvendig. Ved lavdoseteknikker kan støynivået på høyoppløsningsbildene øke betydelig på bekostning av geometrisk oppløsning. Vi anbefaler derfor CTDI (Computed Tomography Dose Index) i størrelsesorden 5-10 mGy.

Ved utredning av mistenkte komplikasjoner benyttes kontrastmiddel på indikasjon. Ved relativ kontraindikasjon for kontrastmiddel kan spektral-CT (dobbeltenergiteknikk) benyttes for å redusere kontrastmiddelvolumet og samtidig oppnå adekvat bildekvalitet, for eksempel for å påvise lungeemboluser.

FUNN

Typiske CT-funn varierer med symptomvarighet og kan deles i tre stadier: en tidlig fase, en intermediær fase som strekker seg fra 3-5 dager etter symptomdebut, og en senfase. Det er ikke alltid funn på CT de første dagene etter symptomdebut. I et materiale med symptomatiske, men uspesifiserte pasienter hadde $56 \%$ normale funn på CT innen to dager etter symptomdebut (12), avtakende til 9\% 3-5 dager etter symptomdebut og $4 \%$ 6-12 dager etter symptomdebut. Funnhyppighet varierer med sykdommens alvorlighetsgrad. Ved første gangs bildediagnostikk var det normale funn hos $18 \% \mathrm{i}$ en gruppe pasienter med ikke alvorlig sykdom, men hos bare $3 \%$ av pasienter med alvorlig sykdom (15). Typiske CT-funn er multiple, bilaterale mattglassfortetninger med perifer distribusjon, hyppigst lokalisert i 
underlappene. I intermediær fase er det økende innslag av konsolidering (tette infiltrater) og affeksjon av flere lapper samt økt septering med brosteinsmønster (crazy paving) som tegn på interstitiell affeksjon. I senfasen er det $\emptyset$ kende total utbredelse, men mattglassfortetninger og konsolidering er fremdeles dominerende funn $(\underline{12}, \underline{16})$. Figur 4 , figur 5 og figur 6 viser typiske funn på CT i ulike faser av covid-19.

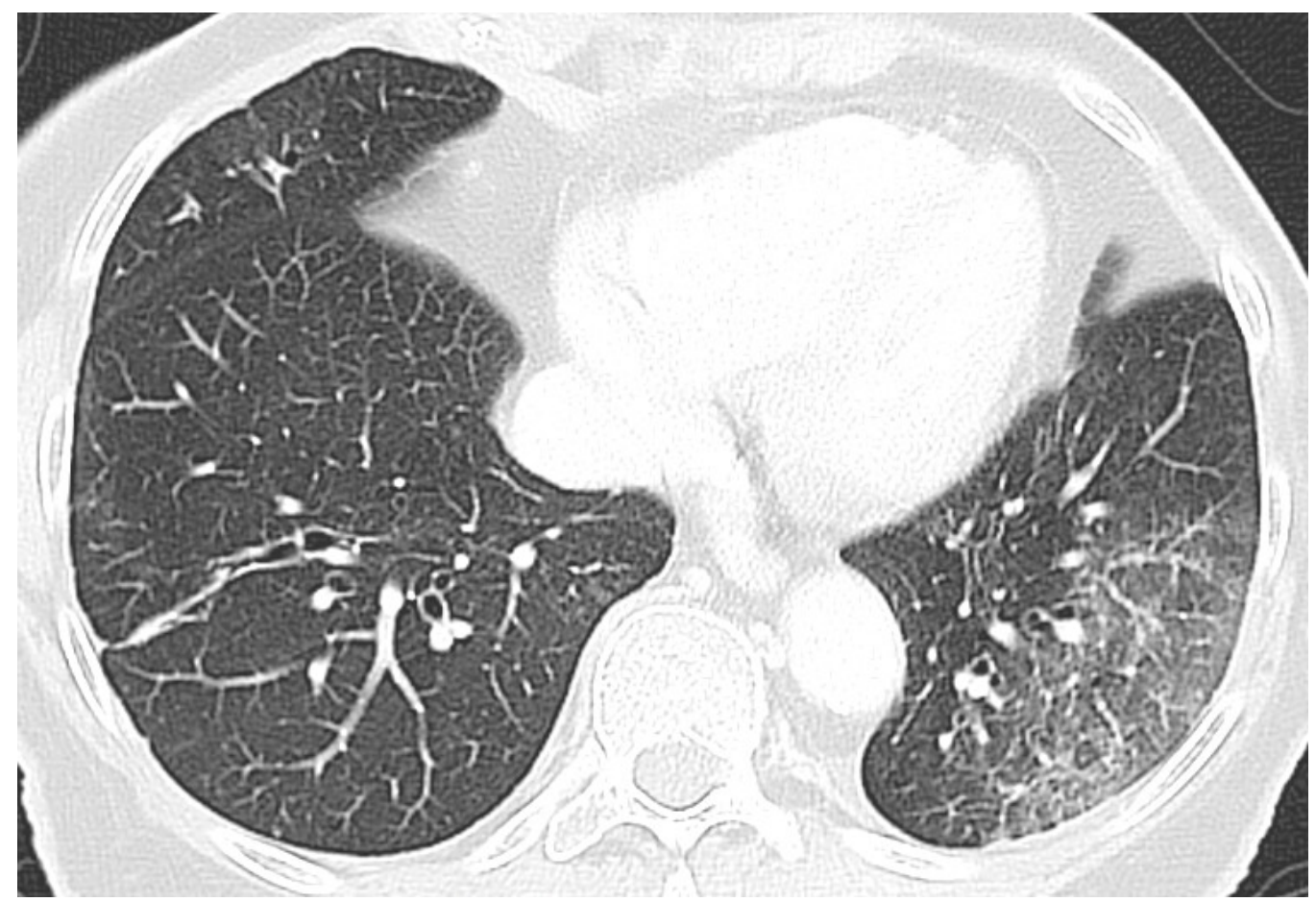

Figur 4 Pasient med covid-19 med nedsatt allmenntilstand, kvalme, oppkast, synkope og mulige frostrier. CT thorax to dager etter symptomdebut viser mattglassfortetninger tydeligst nedad og perifert i venstre lunge.

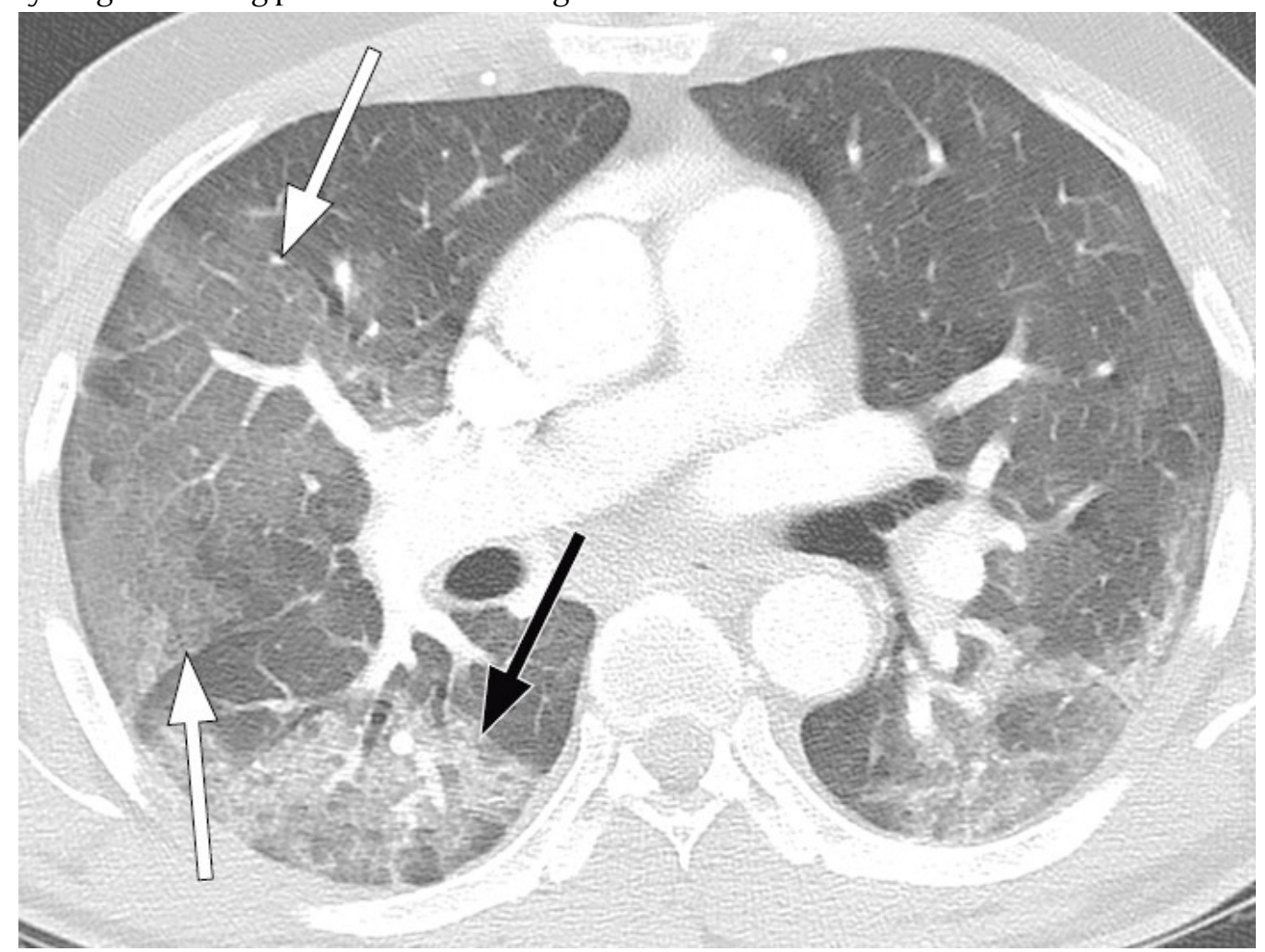

Figur 5 Pasient med covid-19. CT thorax syv dager etter symptomdebut viser utbredte bilaterale mattglassfortetninger (hvite piler), bare i liten grad konsolidering (sort pil). 


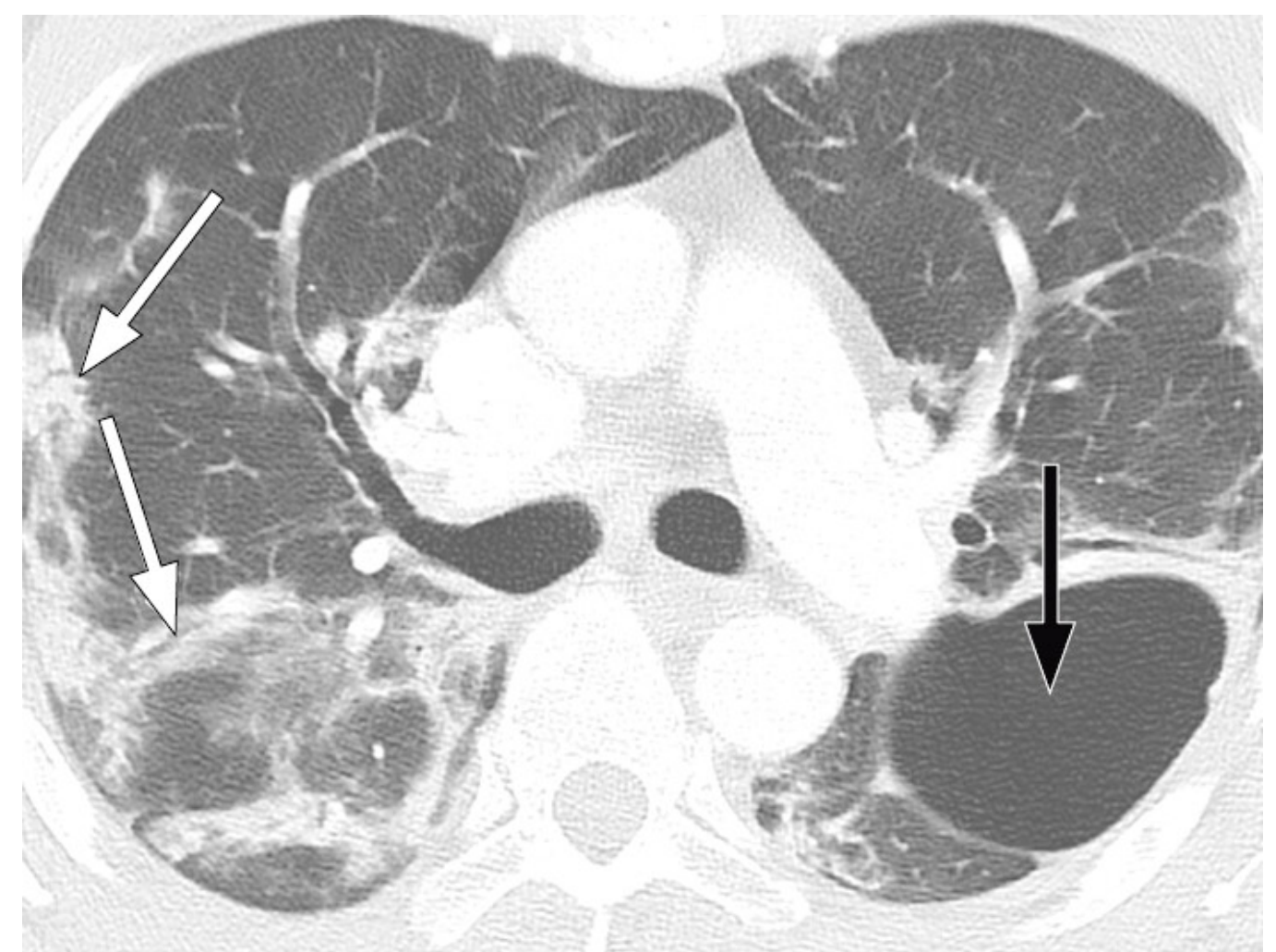

Figur 6 Pasient med Covid-19. CT thorax 20 dager etter symptomdebut viser bilaterale fortetninger med perifer og peribronkovaskulær distribusjon. Bronkiektasier (hvit piler) og en luftfylt kavitet (sort pil) i venstre lunge gir holdepunkter for organisering.

Ved alvorlig sykdomsforløp kan det påvises distorsjon av lungearkitekturen, traksjonsbronkiektasier, forstørrede lymfeknuter og pleuravæske. Dette er funn som ikke er spesifikke for covid-19 (17.).

\section{FØLSOMHET}

Undersøkelsens sensitivitet i påvisning av covid-19-pneumonier er angitt å være opptil $97 \%$ $(\underline{18}, 19)$, og kan da være mer sensitiv enn PCR av prøve fra øvre luftveier $(\underline{18}, \underline{20}, \underline{21})$. Det er holdepunkter for at virusmengden er betydelig høyere i nedre luftveier enn i øvre luftveier ved covid-19-pneumoni (묘, 9.). Påvisning av sars-CoV-2-RNA ved pneumoni bør derfor omfatte prøver fra nedre luftveier ( $\underline{8})$. CT-forandringer ble inkludert som et viktig diagnostikum (major evidence) i Hubei etter 12. februar 2020 (22). Rapporter om CT-funn før klinisk symptomdebut (23) er bakgrunnen for forslag om å benytte CT som screeningverktøy - sammen med PCR - for pasienter med smitterisiko og der det mistenkes falskt negativ PCR-test (24). . Ved lav pretestsannsynlighet for sykdom har imidlertid CT lav positiv prediktiv verdi (25), og toneangivende miljøer i Europa og USA har advart mot å benytte CT som screeningverktøy $(\underline{2}, \underline{4}, \underline{26})$. Tidsrommet fra symptomdebut til funn på CT er dessuten varierende, hvilket innebærer at covid-19 ikke kan utelukkes med normal CT tidlig etter symptomdebut.

Lungeforandringene ved covid-19 er uspesifikke og overlapper med funn ved andre akutte interstitielle pneumonier, inkludert influensa $(\underline{27}, \underline{28})$. Som tilfeldig funn på CTundersøkelse gjort på annen indikasjon, bør likevel forandringene under en pågående pandemi føre til snarlig covid-19-testing.

\section{INDIKASJONER}

CT anbefales ikke som screeningverktøy for covid-19. CT bør kun brukes ved pasienter med uavklarte symptomer etter systematisk klinisk vurdering. CT kan vurderes i førstelinje ved signifikante symptomer som behandlingstrengende dyspné, ved negativ eller uavklart PCR, når avklaring av smitte har konsekvenser, ved uavklarte funn på røntgen thorax samt hos pasienter med underliggende sykdommer som diabetes, overvekt og kronisk lungesykdom. 
Covid-19 kan også debutere med magesmerter, særlig som akutt abdomen kombinert med feber (29). Vi anbefaler årvåkenhet overfor slike atypiske symptomer, og radiologer kan vurdere å utvide en bestilt CT-undersøkelse av buken med tillegg av thorax i samarbeid med klinisk lege (209,30).

Sykdommen kan også presentere seg med forvirring eller redusert bevissthetsnivå, noe som kan forhindre god innhenting av smitte- eller karantenestatus. Også for denne pasientgruppen kan det være aktuelt å gjøre akutt CT thorax under dråpesmitteregime, først og fremst om de likevel gjennomgår annen CT-undersøkelse.

Hos pasienter med akutt lungesviktsyndrom (ARDS) kan CT gi nyttig informasjon om tilgjengelig, ventilerbart lungevolum for å optimalisere ventilering (311,32), og det kan være vesentlig å avklare eventuelle bullae eller pneumothorax. Hos pasienter med bekreftet covid-19 kan CT være indisert ved mistanke om komplikasjoner som lungeembolisme eller superinfeksjon (figur 7) og i oppfølging av uavklarte funn på røntgen thorax.

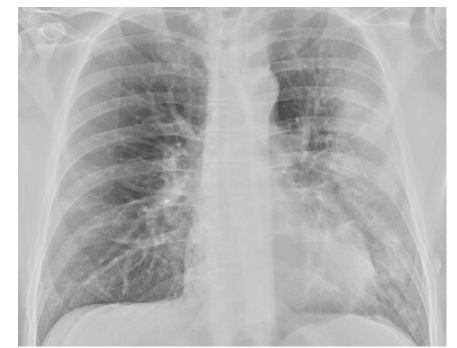

a
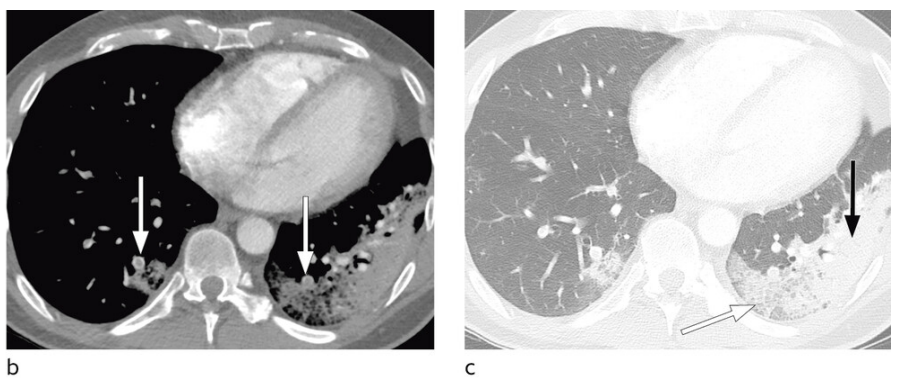

Figur 7 a) Pasient med covid-19 innlagt på sykehus på grunn av nedsatt allmenntilstand. Røntgen thorax tatt sittende i seng med mobilt apparat 11 dager etter symptomdebut) viser fortetninger perifert på venstre side, høyre lunge er klar. b) 16 dager etter symptomdebut tilkom klinisk mistanke om lungeembolisme. CT thorax med kontrastmiddel intravenøst viser perifere lungeemboluser bilateralt (hvite piler). c) Samme snittnivå fremstilt i lungevindu viser perifere fortetninger både av mattglasstype med «crazy paving» (brosteinsmønster) (hvit pil) og konsoliderte fortetninger (sort pil), mest uttalt på venstre side.

\section{Ultralyd thorax}

Ved behov for diagnostikk og tapping av pleuravæske er ultralyd et viktig hjelpemiddel. Ultralyd kan også fremstille forandringer ved covid-19-pneumoni, som subpleurale konsolideringer, alveolære konsolideringer, pleurafortykkelse og B-linjer som vises som haleformede artefakter $(33,34$ ). Den er ikke egnet til å skjelne bakteriell etiologi fra virus. Andre årsaker til akutt lungesviktsyndrom-lignende symptomer kan også gi tilsvarende forandringer på ultralyd.

Ultralyd thorax kan spille en rolle ved terapimonitorering ved kjent sykdom. Eventuell CT vil fremstille disse forandringene mer objektivt, men en fordel ved ultralyd er at undersøkelsen kan gjøres ved sengen hos alvorlig syke pasienter. Ulempen er at denne er operatøravhengig, og en erfaren radiolog eller intensivlege er nødvendig for å sikre klinisk meningsfulle undersøkelser. Derfor kan vi ikke gi en generell anbefaling av denne metoden.

\section{Ekkokardiografi}

Høy alder, mannlig kjønn, hypertensjon, annen kardiovaskulær sykdom og diabetes gir økt risiko for alvorlig forløp av covid-19-infeksjon (35). Både infeksjonen i seg selv og lungesvikt i form av akutt lungesviktsyndrom, med økt stress og fare for hypoksi, gir risiko for myokardskade og/eller -iskemi. Ved troponinutslipp, arytmier og hjertesvikt kan ekkokardiografi være vesentlig for avklaring (35), men er bare indisert når denne har 
sannsynlig betydning for behandlingen. Mange problemstillinger kan avklares ved sengen med håndholdt ultralydapparat (3므). Smittevernutfordringen er minst like stor som ved annen ultralydundersøkelse. Ved hjerteinfarkt er invasiv diagnostikk og behandling aktuelt.

\section{CT og MR av hjernen}

I en retrospektiv studie fra Wuhan i Kina hadde $36 \%$ av hospitaliserte pasienter med covid19 nevrologiske symptomer (37.). Vanligste symptomer var akutt cerebrovaskulær sykdom, bevissthetsforstyrrelser og skjelett- og muskelsymptomer. Hodepine og redusert smaks- og luktesans var også inkludert blant funnene og var vanligere hos mer alvorlig syke. Cerebrale forandringer som ved hemoragisk encefalitt er også beskrevet (3으), en alvorlig komplikasjon som kan oppstå i forbindelse med intrakranial cytokinstorm. Disse studiene taler for at covid-19 også kan gi indikasjon for intrakraniale undersøkelser enten med CT eller MR, primært med tanke på behandlingskrevende iskemi.

\section{LITTERATUR}

1. Rubin GD, Ryerson CJ, Haramati LB et al. The role of chest imaging in patient management during the COVID-19 pandemic: A multinational consensus statement from the Fleischner Society. Radiology 2020; 295: 201365. [PubMed][CrossRef]

2. Revel MP, Parkar AP, Prosch H et al. COVID-19 patients and the radiology department - advice from the European Society of Radiology (ESR) and the European Society of Thoracic Imaging (ESTI). Eur Radiol 2020;30. doi:10.1007/soo330-020-06865-y. [PubMed][CrossRef]

3. Rodrigues JCL, Hare SS, Edey A et al. An update on COVID-19 for the radiologist - A British society of Thoracic Imaging statement. Clin Radiol 2020; 75:323-5. [PubMed]

4. The American College of Radiology. ACR Recommendations for the use of Chest Radiography and Computed Tomography (CT) for Suspected COVID-19 Infection. https://www.acr.org/Advocacy-andEconomics/ACR-Position-Statements/Recommendations-for-Chest-Radiography-and-CT-forSuspected-COVID19-Infection Lest 11.4.2020.

5. Brurberg KG, Fretheim A. Aerosolgenererende prosedyrer i helsetjenesten, og covid-19. Oslo: Folkehelseinstituttet, 2020. https://www.fhi.no/publ/2020/aerosolgenererende-prosedyrer-ihelsetjenesten-og-covid-19/ Lest 27-4.2020.

6. Corman VM, Landt O, Kaiser M et al. Detection of 2019 novel coronavirus (2019-nCoV) by real-time RT-PCR. Euro Surveill 2020; 25: 2000045. [PubMed]

7. Folkehelseinstituttet. Prøvetaking - praktisk gjennomføring. https://www.fhi.no/nettpub/coronavirus/helsepersonell/provetaking/ Lest 11.4.2020.

8. World Health organization. Clinical management of severe acute respiratory infection when COVID-19 is suspected. WHO reference number: WHO/2019-nCoV/clinical/2020.4.

https://www.who.int/publications-detail/clinical-management-of-severe-acute-respiratory-infectionwhen-novel-coronavirus-(ncov)-infection-is-suspected Lest 27.4.2020.

9. Wölfel R, Corman VM, Guggemos W et al. Virological assessment of hospitalized patients with COVID-2019. Nature 2020; 580. doi:10.1038/s41586-020-2196-x. [PubMed][CrossRef]

10. Lescure FX, Bouadma L, Nguyen D et al. Clinical and virological data of the first cases of COVID-19 in Europe: a case series. Lancet Infect Dis 2020; 20: S1473-3099(20)30200-o. [PubMed][CrossRef]

11. Broberg E, Keramarou M, Ködmön C et al. An overview of the rapid test situation for COVID-19 diagnosis in the EU/EEA. Technical Report. European Centre for Disease Prevention and Control, 2020. https://www.ecdc.europa.eu/sites/default/files/documents/Overview-rapid-test-situation-for-COVID19-diagnosis-EU-EEA.pdf Lest 11.4.2020.

12. Bernheim A, Mei X, Huang M et al. Chest CT findings in coronavirus disease-19 (COVID-19): Relationship to duration of infection. Radiology 2020; 295: 200463. [PubMed][CrossRef]

13. Inui S, Fujikawa A, Jitsu M et al. Chest CT findings in cases from the cruise ship "Diamond Princess" with coronavirus disease 2019 (COVID-19). Radiology 2020; 295. doi:10.1148/ryct.2020200110. [CrossRef]

14. Wong HYF, Lam HYS, Fong AHT et al. Frequency and distribution of chest radiographic findings in COVID-19 positive patients. Radiology 2019; 295: 20116o. [PubMed][CrossRef] 
15. Guan WJ, Ni ZY, Hu Y et al. Clinical characteristics of coronavirus disease 2019 in China. N Engl J Med 2020;382. doi: 10.1056/NEJMoa2002032. [PubMed][CrossRef]

16. Wang Y, Dong C, Hu Y et al. Temporal changes of CT findings in 90 patients with COVID-19 pneumonia: A longitudinal study. Radiology 2020; 295: 200843. [PubMed]

17. Zhao W, Zhong Z, Xie X et al. Relation between chest CT findings and clinical conditions of coronavirus disease (COVID-19) pneumonia: A multicenter study. AJR Am J Roentgenol 2020; 214: 1072-7. [PubMed]

18. Ai T, Yang Z, Hou H et al. Correlation of chest CT and RT-PCR testing in coronavirus disease 2019 (COVID-19) in China: A report of 1014 cases. Radiology 2020; 295: 200642. [PubMed][CrossRef]

19. Caruso D, Zerunian M, Polici M et al. Chest CT Features of COVID-19 in Rome, Italy. Radiology 2020; 295: 201237. [PubMed][CrossRef]

20. Xie X, Zhong Z, Zhao W et al. Chest CT for typical 2019-nCoV pneumonia: Relationship to negative RT-PCR testing. Radiology 2020; 295: 200343. [PubMed][CrossRef]

21. Huang P, Liu T, Huang L et al. Use of chest CT in combination with negative RT-PCR assay for the 2019 novel coronavirus but high clinical suspicion. Radiology 2020; 295: 22-3. [PubMed][CrossRef]

22. Zu ZY, Jiang MD, Xu PP et al. Coronavirus disease 2019 (COVID-19): A perspective from China. Radiology 2020; 295: 200490. [PubMed][CrossRef]

23. Shi $\mathrm{H}$, Han X, Jiang $\mathrm{N}$ et al. Radiological findings from 81 patients with COVID-19 pneumonia in Wuhan, China: a descriptive study. Lancet Infect Dis 2020; 20: 425-34. [PubMed]

24. Lee EYP, Ng MY, Khong PL. COVID-19 pneumonia: what has CT taught us? Lancet Infect Dis 2020; 20:384-5. [PubMed]

25. Kim H, Hong H, Yoon SH. Diagnostic performance of CT and reverse transcriptase-polymerase chain reaction for coronavirus disease 2019: A meta-analysis. Radiology 2020; 295: 201343. [PubMed] [CrossRef]

26. The Royal College of Radiologists. RCR position on the role of CT in patients suspected with COVID-19 infection. https://www.rcr.ac.uk/college/coronavirus-covid-19-what-rcr-doing/clinicalinformation/rcr-position-role-ct-patients Lest 10.4.2020.

27. Kooraki S, Hosseiny M, Myers L et al. Coronavirus (COVID-19) outbreak: What the department of radiology should know. J Am Coll Radiol 2020; 17: 447-51. [PubMed]

28. Li Y, Xia L. Coronavirus disease 2019 (COVID-19): Role of chest CT in diagnosis and management. AJR Am J Roentgenol 2020; 214: 1-7. [PubMed]

29. Sellevoll HB, Saeed U, Young VS et al. Covid-19 med akutte magesmerter som debutsymptom. Tidsskr Nor Legeforen 2020;140. doi: 10.4045/tidsskr.20.0262. [CrossRef]

30. BMJ Best Practice. Coronavirus disease 2019 (COVID-19). https://bestpractice.bmj.com/topics/en$\mathrm{gb} / 3000168$ Lest 22.4.2020.

31. Gattinoni L, Pesenti A. The concept of "baby lung". Intensive Care Med 2005; 31: 776-84. [PubMed]

32. Pesenti A, Musch G, Lichtenstein D et al. Imaging in acute respiratory distress syndrome. Intensive Care Med 2016; 42: 686-98. [PubMed]

33. Soldati G, Smargiassi A, Inchingolo R et al. Is there a role for lung ultrasound during the COVID-19 pandemic? J Ultrasound Med 2020;39. doi: 10.1002/jum.15284. [PubMed][CrossRef]

34. Buonsenso D, Pata D, Chiaretti A. COVID-19 outbreak: less stethoscope, more ultrasound. Lancet Respir Med 2020; 8: S2213-26oo(20)30120-X. [PubMed][CrossRef]

35. Madjij M, Safavi-Naeini P, Solomon SD et al. Potential effects of coronaviruses on the cardiovascular system: A review. JAMA Cardiol 2020; 5. doi: 10.1001/jamacardio.2020.1286. [CrossRef]

36. Skulstad H, Cosyns B, Popescu BA et al. COVID-19 pandemic and cardiac imaging: EACVI recommendations on precautions, indications, prioritization, and protection for patients and healthcare personnel. Eur Heart J Cardiovasc Imaging 2020; 21: 1-7. [PubMed]

37. Mao L, Wang M, Chen S et al. Neurological Manifestations of Hospitalized Patients with COVID-19 in Wuhan, China: a retrospective case series study. medRxiv 2020 doi: 10.1101/2020.02.22.20026500. [CrossRef]

38. Poyiadji N, Shahin G, Noujaim D et al. COVID-19-associated acute hemorrhagic necrotizing encephalopathy: CT and MRI features. Radiology 2020; 295: 201187. [PubMed][CrossRef]

Publisert: 5. mai 2020. Tidsskr Nor Legeforen. DOI:10.4045/tidsskr.20.0332

Mottatt 14.4.2020, første revisjon innsendt 24.4.2020, godkjent 27.4.2020. 
(C) Tidsskrift for Den norske legeforening 2023. Lastet ned fra tidsskriftet.no 26. april 2023. 